Operations Research and Applications : An International Journal (ORAJ), Vol.4, No.1, February 2017

\title{
A Multiple Production Setups INVENTORY MODEL FOR IMPERFECT ITEMS CONSIDERING SALVAge VAlUE AND Reducing ENVIRonmental Pollution
}

\author{
R. Uthayakumar ${ }^{1}$ and T. Sekar* \\ ${ }^{1}$ Department of Mathematics, \\ The Gandhigram Rural Institute - Deemed University, \\ Gandhigram - 624 302, Dindigul, Tamilnadu, India, \\ *Department of mathematics, \\ EBET Group of institutions, Tirupur - 638 108, \\ Tamil Nadu, India.
}

\begin{abstract}
This paper presents an imperfect manufacturing system in which production ability can produce items in $m$ production setups and rework the imperfect quality items in one rework setup. Rework is one of the main issues in reverse logistic and green supply chain to reduce production cost and environmental problem. The aim of this research is to minimize the total inventory cost by determining the optimal cycle time and the optimal number of production setups. The convexity of the inventory model is derived by using mathematical software. The result is illustrated with numerical example for the model. The effects of the problem parameters upon the optimal solution are examined numerically. This model can be applied to optimizing the total inventory cost for the business enterprises where production rate and demand rate are time dependent and salvage value is incorporated to the deteriorated items.
\end{abstract}

\section{KEYWORDS}

Deteriorating items, Rework, Salvage value, Linear time varying demand

\section{INTRODUCTION:}

The Economic Production Quantity (EPQ) model is commonly used by practitioners in the fields of production, inventory control and management to assist them in making decision on production lot size. Many researchers have discussed on the EPQ model for the multi-production setups. But very few of them have discussed on multi-production setups with rework. Rework is common in Semiconductor, Pharmaceutical, Chemical, Food industries, Textile industries, Paper industries, Glass industries, Metal processing industries and Plastic industries. Barketau et al. (2008);

DOI : 10.5121/oraj.2017.4101 
Buscher et al. (2007); Chiu et al. (2007). Ca'rdenas-Barrón n, L.E., (2008) presented rework with single stage of production system. Recently, rework process have attracted considerable attention because of the reduction of the natural resources and the rise of cost of the raw material. Rework process play an important role in eliminating waste and effectively controlling the cost of manufacturing in a production system. Therefore, determining optimal lot size in a system that allows rework is a useful objective to minimize the total inventory cost. Rework process reduces energy use and save more natural resources for the future generations. Therefore, the companies are contributing to sustainable development.

In this paper, we consider a multi-production setups and one rework setup. By this EPQ model, it is determined that optimal production setup and optimal production time. Since production process in each production setup is imperfect because of human mistakes, (Drury and Prabhu, (1994)), non-perfect technology or many other factors, the imperfect items are produced during production period. In order to provide good service to customers, after each production setup, inspection is carried out to screen out the imperfect quality items and the deteriorating items. The imperfect quality items found is stocked separately in an inventory until reach the optimal production setup. The rework process starts immediately after determined production setup ends. The perfect quality items produced in each production setup is stored separately in an inventory and sold to customers immediately. Both perfect and imperfect items are considered as deteriorating items because their values go down with time. After determined production setup ends, the imperfect items are sent to rework. When the waiting time of the imperfective quality items exceeds the deterioration time limit, they cannot be recovered and must be disposed. The rework process manufactures all imperfect quality items as perfect quality items. We assume all imperfect items after rework are considered as new. This perfect quality items are sold to customers to satisfy the demand immediately. Production process with rework setup is shown in Fig. 1.

The remainder of this paper is organized as follows. In Section 2, we give a literature review. In section 3, assumptions and notations are given. The mathematical formulation for this model is given in section 4. Numerical example and sensitivity analysis are given in Section 5, and conclusions are drawn in Section 6.

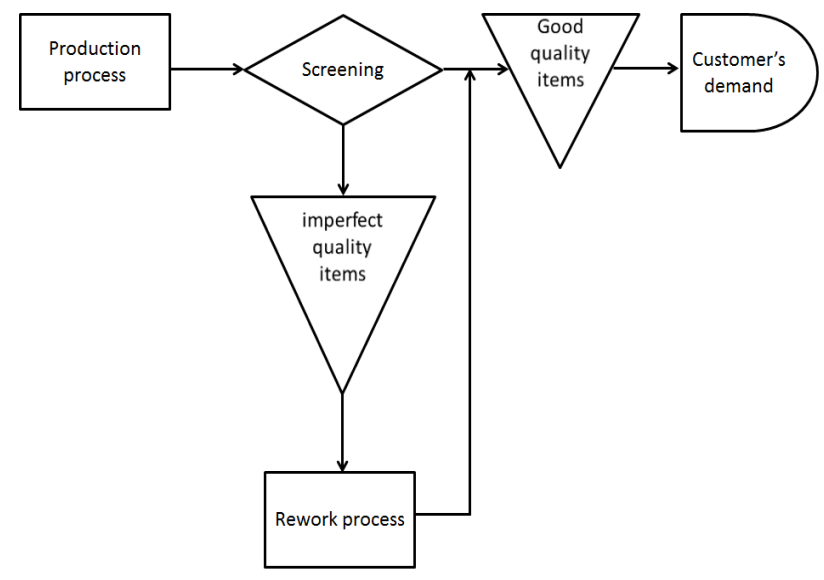

Figure-1: Production process with rework setup. 


\section{LITERATURE REVIEW:}

Economic Production Quantity (EPQ) model is one of the prominent research topics in production, inventory control and management. By using EPQ model, optimal quantity of items and optimal production time can be obtained. Classical EPQ model was developed under various assumptions. Since then, researchers have extended the model by relaxing one or more of its assumptions. It was assumed that the items produced are of perfect quality items in the classical model. However, imperfect quality items may be produced in reality. Wee et al., (2007) extended the model by considering random defective rate. Jaber et al. (2008) assumed the percentage defective per lot reduces according to a learning curve. Mukhopadhyay et al. (2015) investigated an economic production quantity model for three types of imperfect items with rework. Vandana et al. (2015) presented an inventory model for non-instantaneous deteriorating items with quadratic demand rate and shortages under trade credit policy. Rezaei et al. (2001) considered a supply chain with multiple products and multiple suppliers. Chung et al. (2009) proposed an inventory model with two warehouses, where one of them was rented. Yassine et al. (2012) considered disaggregating the shipments of imperfect quality items in a single production run and aggregating the shipments of imperfect items over multiple production runs. Kumar et al. (2011) presented Economic Production Lot Size (EPLS) model with the stochastic demand and shortage partial backlogging rate under imperfect quality items, in which stochastic imperfect production was assumed. Singh et al. (2015) presented a mathematical production inventory model for deteriorating items with time dependent demand rate under the effect of the inflation and shortages. Rezaei et al. (2012) discussed an economic production quantity and purchasing price for items with imperfect quality when inspection shifts from buyer to supplier. Vandana et al. (2016) investigated an EOQ model for retailers partial permissible delay in payment linked to order quantity with shortages. Felix. et al. (2015) presented a modified EPQ model with deteriorating production system and deteriorating product where rework process was considered at the end of production setup. Mishra. V.K, et al. (2013) considered an inventory model for deteriorating items with time-dependent demand and time varying holding cost under partial backlogging. Shilpi Pal et al. (2015) proposed a production inventory model for deteriorating item with ramp type demand allowing inflation and shortages under fuzziness, in which, multiproduction setup was considered without rework. Chandra et al. (2015) introduced the effect of deterioration on two-warehouse inventory model with imperfect quality items. Vandana et al. (2015) introduced an EPQ inventory model for non-instantaneous deteriorating item under trade credit policy. Mishra (2007) derived some problems on approximations of functions in Banach spaces. Deepmala (2014) proposed a study on fixed point theorems for nonlinear contractions and its applications.

Rework process is also one of the important issue in reverse logistics where used products are reworked to reduce total inventory cost, waste and environmental pollution. The earliest research that focused on rework and remanufacturing process was done by Schrady (1967). Since then, researchers on rework have attracted many researchers. Khouja (2000) considered direct rework for Economic Lot Sizing and Delivery Scheduling Problem (ELDSP). Koh et al. (2002) discussed on production inventory models where supplier can fill the demand in two alternatives: either orders new products externally or recovers defective items are reworked in the same cycle; and in the second policy, rework is completed after N cycles. Inderfuth et al. (2005) considered an EPQ model with rework and deteriorating recoverable products. Yoo et al. (2009) developed an EPQ model with imperfect production, imperfect inspection and rework. Widyadana et al. (2012) proposed an EPQ model for deteriorating items with rework which was performed after $\mathrm{m}$ 
production setups. Tai (2013) proposed an EPQ model for deteriorating/imperfect product with rework which was performed after a production setup. Sarkara et al. (2014) assumed rework for single stage production system. Hsu et al. (2014) considered An EPQ model under an imperfect production process with shortages backordered. Singh et al. (2014) proposed an economic production model for time dependent demand with rework and multiple production setups where production is demand dependent.

We notice that not many studies considered a model with multi-production setups, imperfect items, rework and salvage value is incorporated to the deteriorated items. In this paper, we intend to providing analytic results to solve the issues said above.

\section{Assumptions And Notations}

\subsection{AsSumptions}

1. Demand rate of finished products at any time ' $t$ ' in $(0, T)$ is $D(t)$ and assumed to be linearly decreasing.

2. Production rate is demand dependent i. e, $P=\lambda D(t)$ where $\lambda \geq 1$.

3. Rework and deterioration rate are constants.

4. There is a replacement for deteriorated items.

5. Shortages and stock outs are not allowed.

6. The production rate of perfect quality items and rework must be greater than the demand rate.

7. No machine breakdown occurs in the production run and rework period.

8. All demands are satisfied.

9. Inspection cost is negligible when compare with other costs.

10. Setup time for rework process is zero.

11. All the imperfect quality items can be reproduced to good quality. No imperfect quality items occurs during the rework process.

\subsection{NOTATIONS}

$\mathrm{D}(\mathrm{t}) \quad$ Demand rate (unit/year)

$\mathrm{P}(\mathrm{t}) \quad$ Production rate (unit/year)

$\mathrm{P}_{\mathrm{r}} \quad$ Rework process rate (unit/year)

$\theta(\mathrm{t}) \quad$ Deterioration rate (unit/year)

$\alpha \quad$ Percentage of good quality items

$\mathrm{m} \quad$ Number of production setup in one cycle

$\mathrm{D}_{\mathrm{i}} \quad$ Total deteriorating units (unit)

$\mathrm{K}_{\mathrm{S}} \quad$ Production setup cost (\$/setup)

$\mathrm{K}_{\mathrm{r}} \quad$ Rework setup cost (\$/setup)

$\mathrm{h}_{\mathrm{s}} \quad$ Perfect quality items holding cost (\$/unit/year)

$\mathrm{h}_{\mathrm{r}} \quad$ Imperfect quality items holding cost (\$/unit/year)

$\mathrm{D}_{\mathrm{c}} \quad$ Deteriorating cost (\$/unit)

$\mathrm{I}_{1} \quad$ Inventory level of perfect quality items in a production period

$\mathrm{I}_{2} \quad$ Inventory level of perfect quality items in a non -production period

$\mathrm{I}_{\mathrm{r} 1} \quad$ Inventory level of imperfect quality items in a production period

$\mathrm{I}_{\mathrm{r} 2} \quad$ Inventory level of imperfect quality items in a non - production period 
Operations Research and Applications : An International Journal (ORAJ), Vol.4, No.1, February 2017

$\mathrm{I}_{\mathrm{r} 3} \quad$ Inventory level of imperfect quality items in a rework production period

$\mathrm{I}_{\mathrm{t} 1} \quad$ Total inventory level of perfect quality items in a production period

$\mathrm{I}_{\mathrm{t} 2} \quad$ Total inventory level of perfect quality items in a non - production period

$\mathrm{I}_{\mathrm{t} 3} \quad$ Total inventory level of perfect quality items in a rework production period

$\mathrm{I}_{\mathrm{t} 4} \quad$ Total inventory level of perfect quality items in a rework non-production Period

$\mathrm{TTI}_{1} \quad$ Total inventory level of imperfect quality items in a production period

$\mathrm{I}_{\mathrm{v} 1} \quad$ Total inventory level of imperfect quality items in $\mathrm{m}$ production periods

$\mathrm{TTI}_{2} \quad$ Total inventory level of imperfect quality items in a non-production period

$\mathrm{I}_{\mathrm{V} 2} \quad$ Total inventory level of imperfect quality items in $\mathrm{m}$ non - production period

$\mathrm{I}_{\mathrm{v} 3}$ Total inventory level of imperfect quality items in a rework setup production period

TRI Total inventory level of imperfect quality items

$\mathrm{I}_{\mathrm{Mr}} \quad$ Maximum inventory level of imperfect quality items in production setups

$\mathrm{I}_{\mathrm{Er}} \quad$ Maximum inventory level of imperfect quality items when rework process started

$\mathrm{T}_{1} \quad$ Regular production period

$\mathrm{T}_{2} \quad$ Non - production period

$\mathrm{T}_{3} \quad$ Rework process period

$\mathrm{T}_{4} \quad$ Rework non-process period

TCT Total cost per unit time

C Cost per unit

$\gamma \mathrm{C} \quad$ Salvage value associated with deteriorated units during a cycle time $(0<\gamma<1)$

\section{Formulation OF THE Model}

The inventory level of perfect quality items in three production setups is shown in Figure -1. The cycle begins with zero inventory and starts at time $t=0$. Production is performed during $\mathrm{T}_{1}$ time period. Since the production quality is not perfect, a percentage $(1-\alpha)$ imperfect items is assumed to occur during the regular production process $\left(\mathrm{T}_{1}\right)$. The amount of imperfect quality items produced per unit time is $(1-\alpha) \mathrm{P}$. The rew ork process starts after m-production setups. The rework process is performed in $\mathrm{T}_{3}$ time period. The Inventory level of perfect items in a production period can be formulated as:

$\frac{d I_{1}\left(t_{1}\right)}{d t_{1}}+\theta I_{1}\left(t_{1)}=\alpha P-D\left(t_{1}\right) \quad 0 \leq t_{1} \leq T_{1}\right.$

where $\mathrm{D}(t)=a-b t$ where $a$ is the intercept and $b$ is the slope of the linearly decreasing demand function. 
Operations Research and Applications : An International Journal (ORAJ), Vol.4, No.1, February 2017

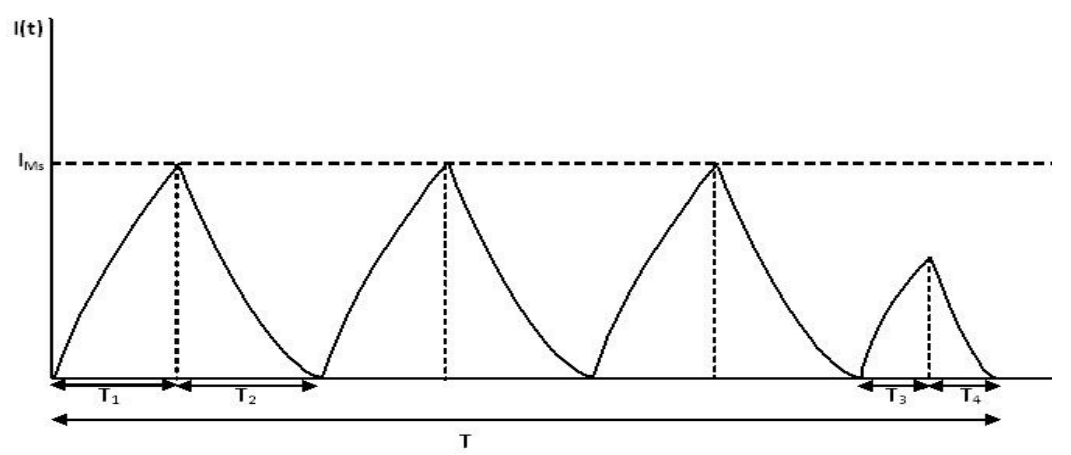

Figure-2: Inventory level of perfect quality items in 3 production setups and 1 rework setup.

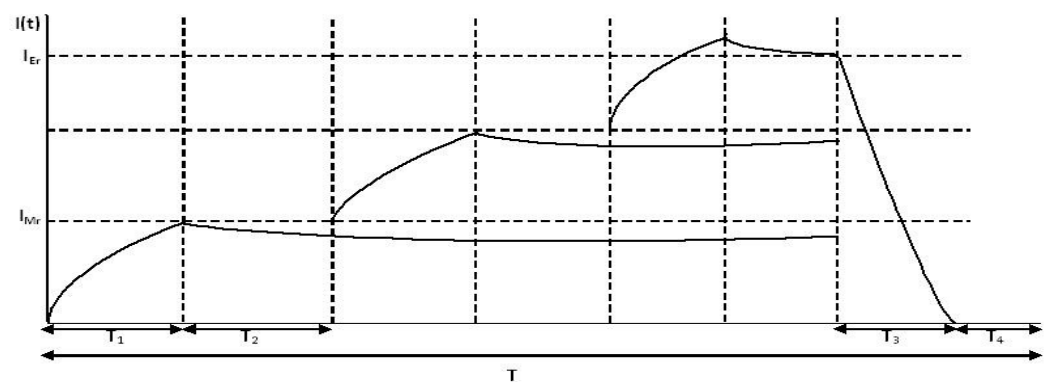

Figure-3: Inventory level of imperfect quality items in 3 production setup and 1 rework setup.

Since $I_{1}(0)=0$, the inventory level in a production period is

$\mathrm{I}_{1}\left(\mathrm{t}_{1}\right)=\frac{\alpha \lambda-1}{\theta}\left[D\left(t_{1}\right)+\frac{b}{a}-e^{-\theta t_{1}}\left(a+\frac{b}{\theta}\right)\right] 0 \leq t_{1} \leq T_{1}$

The total inventory in a production up time can be modeled as

$\mathrm{I}_{\mathrm{t} 1}\left(\mathrm{t}_{1}\right)=\frac{\alpha \lambda-1}{\theta} \int_{0}^{T_{1}}\left[D\left(t_{1}\right)+\frac{b}{a}-e^{-\theta t_{1}}\left(a+\frac{b}{\theta}\right)\right] d t_{1}$
$\mathrm{I}_{\mathrm{t} 1}=\frac{\alpha \lambda-1}{\theta^{2}}\left[\theta a T_{1}-b\left(\frac{\theta T_{1}^{2}}{2}-T_{1}\right)+\left(a+\frac{b}{\theta}\right)\left(e^{-\theta T_{1}}-1\right)\right]$

For small value of $\theta T_{1}$ and using Taylor series approximation, we get

$\mathrm{I}_{\mathrm{t} 1}=\frac{(\alpha \lambda-1) a T_{1}^{2}}{2}$

The inventory level in a non-production period is represented by

$\frac{d I_{2}\left(t_{2}\right)}{d t_{2}}+\theta I_{2}\left(t_{2)}=-D\left(t_{2}\right) \quad 0 \leq t_{2} \leq T_{2}\right.$ 
Since $I_{2}\left(T_{2}\right)=0$ and using similar procedure we get the total inventory in a non-production period can

be represented as

$$
\begin{aligned}
& \mathrm{I}_{\mathrm{t} 2}\left(\mathrm{t}_{2}\right)=\left[\frac{D\left(T_{2}\right)}{\theta}+\frac{b}{\theta^{2}}\right] e^{\theta\left(T_{2}-t_{2}\right)}-\left[\frac{D\left(t_{2}\right)}{\theta}+\frac{b}{\theta^{2}}\right] \\
& \mathrm{I}_{\mathrm{t} 2}=\frac{\mathrm{D}\left(\mathrm{T}_{2}\right) \mathrm{T}_{2}{ }^{2}}{2} .
\end{aligned}
$$

Since $\mathrm{I}_{1}=\mathrm{I}_{2}$ when $t_{1}=T_{1}$ and $t_{2}=0$, we get the total inventory in a non-production period can be represented as

$$
\begin{aligned}
& \frac{\alpha \lambda-1}{\theta}\left[D\left(t_{1}\right)+\frac{b}{a}-e^{-\theta T_{1}}\left(a+\frac{b}{\theta}\right)\right]=\left[\frac{D\left(T_{2}\right)}{\theta}+\frac{b}{\theta^{2}}\right] e^{\theta T_{2}}-\left[\frac{a}{\theta}+\frac{b}{\theta^{2}}\right] \\
& T_{2} \cong \frac{(\alpha \lambda-1)\left[2 a T_{1}-(a \theta+b) T_{1}{ }^{2}\right]}{2 a}
\end{aligned}
$$

Using similar steps as above, the total inventory level of perfect quality items in a rework production period and the total inventory level of perfect quality items in a rework nonproduction period time are derived as follows:

$$
\begin{aligned}
& \mathrm{I}_{\mathrm{t} 3}=\frac{\left(\mathrm{P}_{\mathrm{r}}-a\right) \mathrm{T}_{3}{ }^{2}}{2} \\
& \mathrm{I}_{\mathrm{t} 4}=\frac{D\left(T_{4}\right) \mathrm{T}_{4}{ }^{2}}{2}
\end{aligned}
$$

Since $\mathrm{I}_{3}=\mathrm{I}_{4}$ when $t_{3}=T_{3}$ and $t_{4}=0$, we get

$$
T_{4} \cong \frac{\left(P_{r}-a\right)\left[T_{3}-\frac{\theta T_{3}{ }^{2}}{2}\right]+\frac{b T_{3}{ }^{2}}{2}}{a}
$$

The inventory level of imperfect quality items is shown in Figure-2. The inventory level of imperfect quality items in a production period can be modeled as

$\frac{d I_{r 1}\left(t_{r 1}\right)}{d t_{r 1}}+\theta I_{r 1}\left(t_{r 1)}=(1-\alpha) P \quad 0 \leq t_{r 1} \leq T_{1}\right.$

Since $\mathrm{I}_{\mathrm{r} 1}(0)=0$, the inventory level of imperfect quality items in a production period is 
$I_{r 1}\left(t_{r 1)}=\lambda(\alpha-1)\left\{\left(\frac{a}{\theta}+\frac{b}{\theta^{2}}\right)\left(1-e^{-\theta t_{r 1}}\right)-\frac{b t_{r 1}}{\theta}\right\} \quad 0 \leq t_{r 1} \leq T_{1}\right.$

Using Taylor series approximation, the total inventory level of imperfect quality items in a production up time in one setup is

$\mathrm{TTI}_{1}=\frac{\lambda(1-\alpha) a T_{1}^{2}}{2}$

Since there are $m$ production setups in one cycle, the total inventory level of imperfect quality items in one cycle is:

$\mathrm{I}_{\mathrm{v} 1}=\frac{m \lambda(1-\alpha) a T_{1}^{2}}{2}$

The initial inventory level of imperfect quality items in each production setup is equal to $\mathrm{I}_{\mathrm{Mr}}$ and it can be modeled as:

$\mathrm{I}_{\mathrm{Mr}}=\lambda(1-\alpha)\left[\left(\frac{a}{b}+\frac{b}{\theta^{2}}\right)\left(1-e^{-\theta T_{1}}\right)-\frac{b}{\theta} T_{1}\right]$

Using Taylor series approximation, we get

$\mathrm{I}_{\mathrm{Mr}}=\lambda(1-\alpha)\left[a T_{1}-(a \theta+b) \frac{T_{1}^{2}}{2}\right]$

The inventory level of imperfect quality items in a non-production period as:

$\frac{d I_{r 2}\left(t_{r 2}\right)}{d t_{r 2}}+\theta I_{r 2}\left(t_{r 2)}=0 \quad 0 \leq t_{r 2} \leq(m-1) T_{1}+m T_{2}\right.$

Since the inventory level $I_{r 2}(0)=I_{M r}$, the inventory level of imperfect quality items in a non-production time for each production setup can be modeled as:

$I_{r 2}\left(t_{r 2)}=\mathrm{I}_{\mathrm{Mr}} \mathrm{e}^{-\theta \mathrm{t}_{\mathrm{r} 2}} \quad 0 \leq t_{r 2} \leq(m-1) T_{1}+m T_{2}\right.$

Using Taylor series expansion, the total inventory of imperfect quality items in a production down time in one setup is:

$\mathrm{TTI}_{2}=\sum_{k=1}^{m} \mathrm{I}_{\mathrm{Mr}}\left\{\left[(\mathrm{k}-1) \mathrm{T}_{1}+\mathrm{kT}_{2}\right]-\frac{\theta\left[(\mathrm{k}-1) \mathrm{T}_{1}+\mathrm{kT}_{2}\right]^{2}}{2}\right\}$

The total inventory of imperfect quality items in m production periods can be modeled as follows:

$\mathrm{I}_{\mathrm{v} 2}=\sum_{k=1}^{m} \mathrm{I}_{\mathrm{Mr}}\left\{\left[(\mathrm{k}-1) \mathrm{T}_{1}+\mathrm{kT}_{2}\right]-\frac{\theta\left[(\mathrm{k}-1) \mathrm{T}_{1}+\mathrm{kT}_{2}\right]^{2}}{2}\right\}$

Inventory level of imperfect quality items in the end of production cycle is equal to maximum 
inventory level of imperfect quality items in a production setup reduced by deteriorating rate during production up time and down time. The maximum inventory level of imperfect quality items can be formulated as follows:

$\mathrm{I}_{\mathrm{Er}}=\sum_{k=1}^{m} \mathrm{I}_{\mathrm{Mr}} \mathrm{e}^{-\theta\left[(\mathrm{k}-1) \mathrm{T}_{1}+\mathrm{kT}_{2}\right]}$

Using Taylor series expansion and then substituting $\mathrm{I}_{\mathrm{Mr}}$ we get

$\mathrm{I}_{\mathrm{Er}}=\sum_{k=1}^{m}\left\{\lambda(1-\alpha)\left(a T_{1}-(a \theta+b) \frac{T_{1}^{2}}{2}\right\}\left\{\begin{array}{r}1-\theta\left[(\mathrm{k}-1) \mathrm{T}_{1}+\mathrm{kT}_{2}\right] \\ +\frac{\left\{\theta\left[(\mathrm{k}-1) \mathrm{T}_{1}+\mathrm{kT}_{2}\right]\right\}^{2}}{2}\end{array}\right\}\right.$

The inventory level of imperfect quality items in a rework period can be formulated as:

$\frac{d I_{r 3}\left(t_{r 3}\right)}{d t_{r 3}}+\theta I_{r 3}\left(t_{r 3)}=-P_{r} \quad 0 \leq t_{r 3} \leq T_{3}\right.$

The inventory level of imperfect quality item in a rework period is:

$I_{r 3}\left(t_{r 3)}=\frac{P_{r}}{\theta}\left[e^{\theta\left(T_{3}-T_{r 3}\right)}-1\right]\right.$

The total inventory of imperfect quality items in a rework period is:

$I_{r 3}\left(t_{r 3}\right)=\int_{t_{r 3}=0}^{T_{3}} \frac{P_{r}}{\theta}\left[e^{\theta\left(T_{3}-t_{r 3}\right)}-1\right] d t_{r 3}$

Using Taylor series expansion, we get

$\mathrm{I}_{\mathrm{v} 3}=\frac{\mathrm{P}_{\mathrm{r}} \mathrm{T}_{3}{ }^{2}}{2}$

When $t_{r 3}=0$, the number of imperfect quality items inventory is equal to $\mathrm{I}_{\mathrm{Er}}$. Equation (24) becomes

$\mathrm{I}_{\mathrm{Er}}=\frac{P_{r}}{\theta}\left[e^{\theta T_{3}}-1\right]$

Since $\theta T_{3} \ll 1$ and using Taylor series expansion results in:

$T_{3}=\frac{\mathrm{I}_{\mathrm{Er}}}{P_{r}}$

Substitute $\mathrm{I}_{\text {Er }}$ we have

$T_{3}=\frac{1}{P_{r}} \sum_{k=1}^{m}\left\{\lambda(1-\alpha)\left(a T_{1}-(a \theta+b) \frac{T_{1}^{2}}{2}\right\}\left\{\begin{array}{r}1-\theta\left[(\mathrm{k}-1) \mathrm{T}_{1}+\mathrm{kT}_{2}\right] \\ +\frac{\left\{\theta\left[(\mathrm{k}-1) \mathrm{T}_{1}+\mathrm{kT}_{2}\right]\right\}^{2}}{2}\end{array}\right\}\right.$

The total inventory level of imperfect items is 


$$
\begin{aligned}
& T R I=\mathrm{I}_{\mathrm{v} 1}+\mathrm{I}_{\mathrm{v} 2}+\mathrm{I}_{\mathrm{v} 3} \\
& T R I=\frac{m \lambda(1-\alpha) a T_{1}{ }^{2}}{2}+\sum_{k=1}^{m} \mathrm{I}_{\mathrm{Mr}}\left\{\left[(\mathrm{k}-1) \mathrm{T}_{1}+\mathrm{kT}_{2}\right]-\frac{\theta\left[(\mathrm{k}-1) \mathrm{T}_{1}+\mathrm{kT}_{2}\right]^{2}}{2}\right\}+\frac{\mathrm{P}_{\mathrm{r}} \mathrm{T}_{3}{ }^{2}}{2}
\end{aligned}
$$

The number of deteriorating item is equal to the number of items produced minus the number of total demands. The total deteriorating units can be modeled as:

$D_{i}=\left(m \alpha \lambda T_{1} f(t)+P_{r} T_{3}\right)-D(t)\left[m\left(T_{1}+T_{2}\right)+T_{3}+T_{4}\right]$

The total inventory cost consists of production setup cost, rework setup cost, perfect items inventory cost, imperfect quality items inventory cost and deteriorating cost. The total inventory cost per unit time can be modeled as follows:

$\operatorname{TCT}\left(m, T_{1}\right)=\frac{m k_{s}+k_{r}+h_{s}\left[m\left(\mathrm{I}_{\mathrm{t} 1}+\mathrm{I}_{\mathrm{t} 2}\right)+\mathrm{I}_{\mathrm{t} 3}+\mathrm{I}_{\mathrm{t} 4}\right]+h_{r}(T R I)+D_{C} D_{i}-\gamma C D_{i}}{\left[m\left(\mathrm{~T}_{1}+\mathrm{T}_{2}\right)+\mathrm{T}_{3}+\mathrm{T}_{4}\right]}$

The optimal solution must satisfy the following condition:

$\frac{\partial\left[T C T\left(m, T_{1}\right)\right]}{\partial T_{1}}=0$

And the optimal solution of $\mathrm{m}$, denoted by $m^{*}$, must satisfy the following condition:

$\operatorname{TCT}\left(m^{*}-1, T_{1}\right) \geq \operatorname{TCT}\left(m^{*}, T_{1}\right) \leq \operatorname{TCT}\left(m^{*}+1, T_{1}\right)$

Since the cost function equation (31) is a nonlinear equation and the second derivative of equation (31) with respect to $T_{1}$ is extremely complicated, closed form solution of (31) cannot be derived. However, by means of Maple mathematical software, one can indicate that equation (31) is convex for a small value of $T_{1}$. The optimal $T_{1}$ value can be obtained using Maple mathematical software. Fig- 4 shows that the total cost $\left(\mathrm{TC}_{1}\right)$ per unit time is convex for small values of $\mathrm{T}_{1}$. The optimal total cost is equal to $\$ 1446.17$ when $\mathrm{T}_{1}{ }^{*}=0.03186$ and $m^{*}=3$.

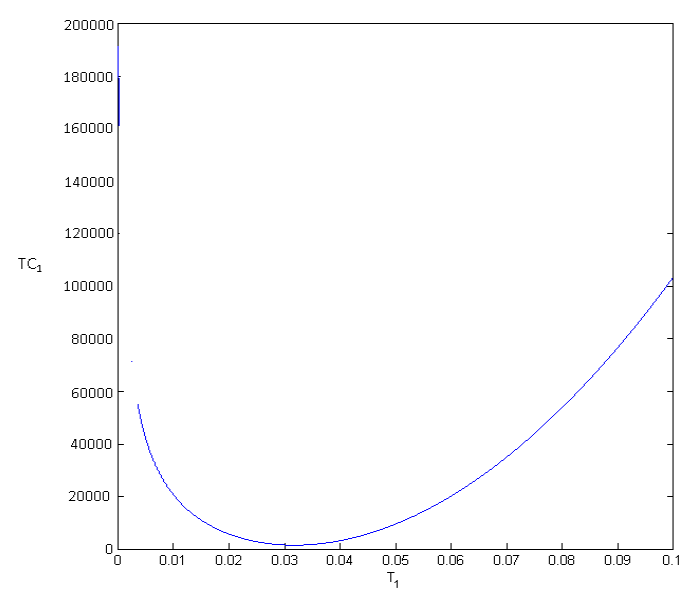

Figure-4: Total cost per unit time in varies of $\mathrm{T}_{1}$ 


\section{Numerical EXample And Sensitivity Analysis}

In this section, a numerical example and sensitivity analysis are given to illustrate the model. Let $\mathrm{K}_{\mathrm{s}}=\$ 8$ per production setup, $\mathrm{K}_{\mathrm{r}}=\$ 5$ per rework setup, $\mathrm{P}_{\mathrm{r}}=10$ units per unit time , $\mathrm{C}=\$$ 1000 per unit, $\mathrm{h}_{\mathrm{s}}=\$ 4$ per unit per unit time, $\mathrm{h}_{\mathrm{r}}=\$ 2$ per unit per unit time, $\mathrm{D}_{\mathrm{c}}=\$ 8$ per unit, $a=$ $100, b=0.2, \lambda=8, \gamma=0.3, \alpha=0.8, \theta=0.06$. The total cost, TC1 $=\mathrm{TCT}(\mathrm{m}, \mathrm{T} 1)$ per unit time for varying $T_{1}$ is shown in Figure-4. Fig-4 shows that the total cost per unit time is convex for small values of $T_{1}$. The optimal total cost is equal to $\$ 1446.17$ when $m^{*}=3$.

The sensitive analysis is performed by changing each of the parameters by $-60 \%,-40 \%,-20 \%$, $+20 \%,+40 \%$ and $+60 \%$. One parameter is taken at a time and the remaining parameters are kept unchanged. The $\mathrm{m}$ and $\mathrm{T}_{1}$ values for different values of parameters are shown in Table1.Table- 1 shows that the number of production setup is sensitive to the changes in parameters $h_{s}, h_{r}$ and $\theta$. The number of production $\operatorname{setup}(m)$ increases with increasing $h_{s}$ and decreases when the value of parameters $h_{r}$ and $\theta$ increase. But the optimal production setup $\left(m^{*}\right)$ is not sensitive to other parameters. The optimal production time $\left(\mathrm{T}_{1}{ }^{*}\right)$ decreases with the increasing $\mathrm{P}_{\mathrm{r}}, a, \mathrm{~h}_{\mathrm{r}}$ and $\mathrm{D}_{\mathrm{c}}$ values and it increases when the value of parameters $\mathrm{K}_{\mathrm{s}}, \mathrm{b}, \gamma, \mathrm{h}_{\mathrm{s}}$ and $\theta$ increase.

The optimal production period for varying parameters is shown in Fig-5. The figure shows that the optimal production period is sensitive to changes in $\theta$, temperately sensitive to changes in $h_{r}$ and insensitive to changes in the other parameters.

The optimal total cost per unit time for varying parameters is shown in Table-2. The Table-2 shows that the total cost per unit time increases when the value of parameters $\mathrm{K}_{\mathrm{s}}, \mathrm{K}_{\mathrm{r}}, a, \gamma$ increases and decreases when the value of parameters $\mathrm{P}_{\mathrm{r}}, b, \mathrm{D}_{\mathrm{c}}$ increases. But there is a fluxuation when changing the parameters $h_{r}, h_{s}$ and $\theta$. The optimal total cost is sensitive to $\theta$, $\mathrm{h}_{\mathrm{s}}, \mathrm{h}_{\mathrm{r}}$ and moderately sensitive to changes in $a, \gamma$ and insensitive to the changes in the other parameters.

Fig-6 shows that the total inventory cost per unit time for varying parameters. The total cost per unit time sensitive to changes in the parameters $\theta, \gamma, h_{s}$ and moderately sensitive to changes in the parameters $a$ and $b$. the inventory cost is insensitive with the other parameters. 
Operations Research and Applications : An International Journal (ORAJ), Vol.4, No.1, February 2017

Table-1: Sensitivity analysis of $\mathrm{m}$ and $\mathrm{T}_{1}$.

\begin{tabular}{|c|c|c|c|c|c|c|c|c|c|c|c|c|}
\hline $\begin{array}{c}\text { Para- } \\
\text { meter }\end{array}$ & \multicolumn{2}{|c|}{$\begin{array}{c}-60 \% \\
\text { changed }\end{array}$} & \multicolumn{2}{c|}{$\begin{array}{c}-40 \% \\
\text { changed }\end{array}$} & \multicolumn{2}{c|}{$\begin{array}{c}-20 \% \\
\text { changed }\end{array}$} & \multicolumn{2}{c|}{$\begin{array}{c}+20 \% \\
\text { changed }\end{array}$} & \multicolumn{2}{|c|}{$\begin{array}{c}+40 \% \\
\text { changed }\end{array}$} & \multicolumn{2}{|c|}{$\begin{array}{c}+60 \% \\
\text { changed }\end{array}$} \\
\hline & $\mathrm{m}$ & $\mathrm{T} 1$ & $\mathrm{~m}$ & $\mathrm{~T} 1$ & $\mathrm{~m}$ & $\mathrm{~T} 1$ & $\mathrm{~m}$ & $\mathrm{~T} 1$ & $\mathrm{~m}$ & $\mathrm{~T} 1$ & $\mathrm{~m}$ & $\mathrm{~T} 1$ \\
\hline $\mathrm{K}_{\mathrm{s}}$ & 3 & 0.03185 & 3 & 0.03185 & 3 & 0.03186 & 3 & 0.03186 & 3 & 0.03187 & 3 & 0.03187 \\
\hline $\mathrm{K}_{\mathrm{r}}$ & 3 & 031860 & 3 & 0.03186 & 3 & 0.03186 & 3 & 0.03186 & 3 & 0.03186 & 3 & 0.03186 \\
\hline $\mathrm{P}_{\mathrm{r}}$ & 3 & 0.03189 & 3 & 0.03188 & 3 & 0.03187 & 3 & 0.03185 & 3 & 0.03184 & 3 & 0.03183 \\
\hline $\mathrm{a}$ & 3 & 0.03265 & 3 & 0.03221 & 3 & 0.03199 & 3 & 0.03177 & 3 & 0.03171 & 3 & 0.03166 \\
\hline $\mathrm{b}$ & 3 & 0.03153 & 3 & 0.03164 & 3 & 0.03175 & 3 & 0.03197 & 3 & 0.03208 & 3 & 0.03219 \\
\hline$\gamma$ & 3 & 0.03142 & 3 & 0.03157 & 3 & 0.03171 & 3 & 0.0320 & 3 & 0.03215 & 3 & 0.03229 \\
\hline $\mathrm{h}_{\mathrm{s}}$ & 2 & 0.03171 & 2 & 0.03263 & 3 & 0.03116 & 3 & 0.03252 & 3 & 0.03314 & 3 & 0.03373 \\
\hline $\mathrm{h}_{\mathrm{r}}$ & 3 & 0.0368 & 3 & 0.03431 & 3 & 0.03285 & 3 & 0.03115 & 2 & 0.03273 & 2 & 0.03221 \\
\hline $\mathrm{D}_{\mathrm{c}}$ & 3 & 0.03187 & 3 & 0.03187 & 3 & 0.03186 & 3 & 0.03186 & 3 & 0.03185 & 3 & 0.03185 \\
\hline$\theta$ & 3 & 0.02248 & 3 & 0.02521 & 3 & 0.02835 & 2 & 0.0381 & 1 & 0.04744 & 1 & 0.05189 \\
\hline$\theta$
\end{tabular}

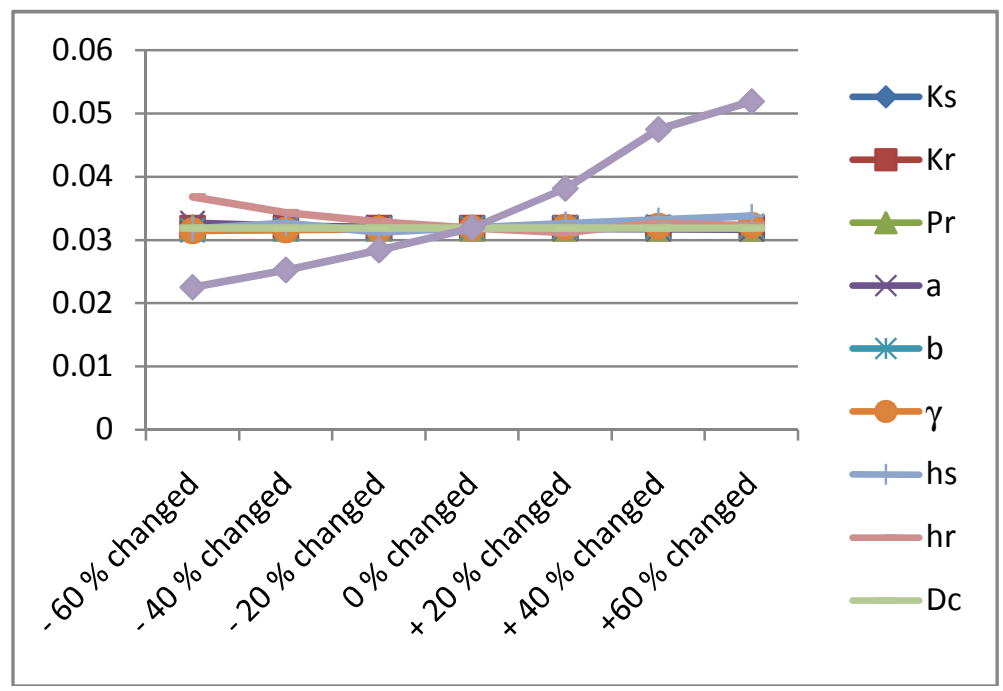

Figure-5: $\mathrm{T}_{1}$ sensitivity analysis

Table-2: Sensitivity analysis for the total cost per unit time(\$) 
Operations Research and Applications : An International Journal (ORAJ), Vol.4, No.1, February 2017

\begin{tabular}{|c|c|c|c|c|c|c|}
\hline $\begin{array}{l}\text { Para- } \\
\text { meter }\end{array}$ & $\begin{array}{c}-60 \% \\
\text { changed }\end{array}$ & $\begin{array}{c}\text { - } 40 \% \\
\text { changed }\end{array}$ & $\begin{array}{c}\text { - } 20 \% \\
\text { changed }\end{array}$ & $\begin{array}{c}+20 \% \\
\text { changed }\end{array}$ & $\begin{array}{c}+40 \% \\
\text { changed }\end{array}$ & $\begin{array}{c}+60 \% \\
\text { changed }\end{array}$ \\
\hline $\mathrm{K}_{\mathrm{s}}$ & 1423.630768 & 1431.144844 & 1438.658467 & 1453.682105 & 1461.192045 & 1468.701608 \\
\hline $\mathrm{K}_{\mathrm{r}}$ & 1441.475399 & 1443.040361 & 1444.605323 & 1447.735248 & 1449.30021 & 1450.865173 \\
\hline $\mathrm{P}_{\mathrm{r}}$ & 1496.999113 & 1480.084067 & 1463.141156 & 1429.171361 & 1412.144288 & 1395.088969 \\
\hline$a$ & 89.34710077 & 544.936701 & 996.3801418 & 1895.135588 & 2343.629474 & 2791.830108 \\
\hline$b$ & 1899.920936 & 1749.304135 & 1598.054555 & 1293.649444 & 1140.490171 & 986.69063 \\
\hline$\gamma$ & 696.4724061 & 947.5418524 & 1197.432327 & 1693.782443 & 1940.291696 & 2185.722348 \\
\hline$h_{s}$ & 817.6149026 & 1992.216038 & 225.3036874 & 2642.342372 & 3816.210375 & 4969.760648 \\
\hline$h_{r}$ & 4636.914177 & 3678.203827 & 2594.017105 & 260.9441034 & 2999.770418 & 2339.404367 \\
\hline$D_{c}$ & 1466.020425 & 1459.404589 & 1452.78819 & 1439.552382 & 1432.933049 & 1426.313076 \\
\hline$\theta$ & 11977.94625 & 8656.874909 & 5172.802685 & 1541.711816 & 4644.169125 & 3221.004949 \\
\hline
\end{tabular}

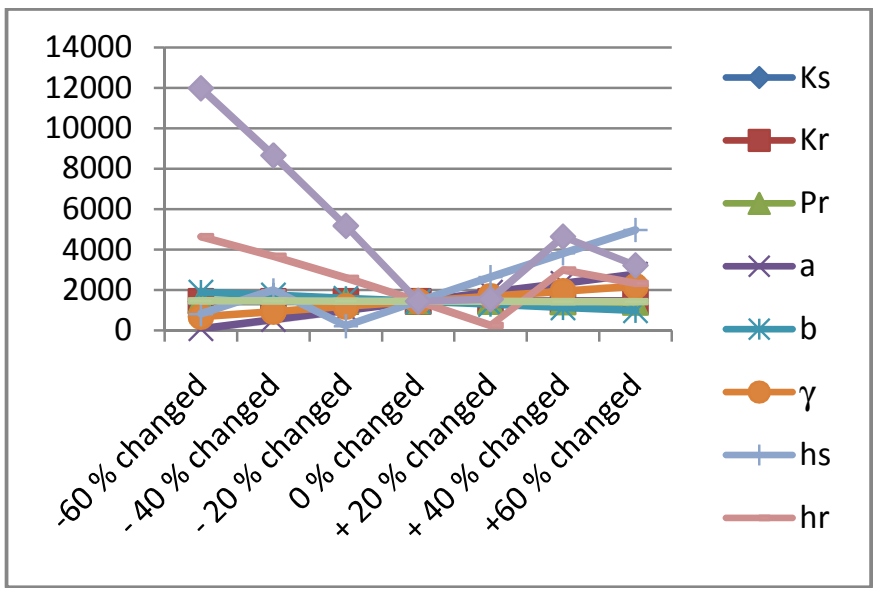

Figure-6: Total cost per unit time sensitivity analysis 


\section{CONCLUSION}

This paper deals with an EPQ model for deteriorating/imperfect quality items with linearly decreasing demand and demand dependent production setup. In this model, imperfect quality items are allowed and reworked to maintain as good quality and goodwill of the customers. This model helps to management to determine number of production setup and optimum production time by minimizing the total inventory cost. Sensitivity analysis shows that the number of production setup decrease when holding cost of perfect quality items decreases and holding cost of imperfect quality items increases and also it shows that both the number of production setups and optimum production time are highly sensitive with deteriorating items. Hence the management has to take vital decisions while maintaining inventory with deteriorating items.

A possible extension for further research may consider multi-production setups with partial/complete backordering where holding cost and deterioration rate are time dependent. This approach can also be extended to other problem by considered delay payment, inflation, unit cash discount, stock-dependent demand and single-vendor single-buyer problem.

\section{REFERENCES}

[1] Barketau, M. S., Cheng T. C. E., Kovalyov, M. Y., (2008). Batch scheduling of deteriorating reworkables. European Journal of Operational Research, 189, 1317-1326.

[2] Buscher, U., Lindner, G., (2007). Optimizing a production system with rework and equal sized batch shipments. Computers and Operations Research, 34, 515-535.

[3] Ca'rdenas-Barro'n, L.E., (2008). Optimal manufacturing batch size with rework in a single-stage production system - A simple derivation. Computers \& Industrial Engineering, 55, 758-765.

[4] Chandra K.J., Tiwari. S., Shafi. A (2015). Effect of deterioration on two-warehouse inventory model with imperfect quality. Computers \& Industrial Engineering 88 (2015) 378-385.

[5] Chiu, S.W., Wang, S.L., Chiu, Y.P., (2007). Determining the optimal run time for EPQ model with scrap, rework, and stochastic breakdowns. European Journal of Operational Research, 180, $\quad 664-$ 676.

[6] Chung, C.J., Wee, H.M., (2011). Short life-cycle deteriorating product remanufacturing in a green supply chain inventory control system. International Journal of Production Economics, 129(1), 195203.

[7] Chung, K.J., Her, C.C., Lin, S.D., (2009). A two-warehouse inventory model with imperfect quality production processes. Computers \& Industrial Engineering, 56(1), 193-97.

[8] Deepmala., (2014). A Study on Fixed Point Theorems for Nonlinear Contractions and its Applications, Ph.D. Thesis. Pt. Ravishankar Shukla University, Raipur (Chhatisgarh) India - 492 010 .

[9] Drury, C. G. (1978). Integrating human factors models into statistical quality control. Human Factors: The Journal of the Human Factors and Ergonomics Society, 20(5), 561-572.

[10] Drury, C. G., Prabhu, P. V., (1994). Human factors in test and inspection. In G. Salvendy \& W. Karwowski (Eds.), Design of work and development of personnel in advanced manufacturing (pp. 355-401). New York: John Wiley \& Sons Inc.

[11] Felix. N. Li., Chan. T.S., Chung. S.H., Allen H. Tai., (2015). A Modified EPQ model with deteriorating production system and deteriorating product. Proceedings of the world congress on mechanical, chemical, and material engineering (MCM 2015). Barcelona, Spain, July 20 - 21, Paper No. 249

[12] Hsu. L.F., Hsu. J. T (2014). Economic production quantity (EPQ) models under an imperfect production process with shortages backordered. International Journal of Systems Science, 47(4), 852-867. 
[13] Inderfuth, K., Lindner, G., Rachaniotis, N.P., (2005). Lot sizing in a production system with rework and product deterioration. International Journal of Production Research 43, 1355-1374.

[14] Jaber, M.Y., Goyal, S.K., Imran, M., (2008). Economic production quantity model for items with imperfect quality subject to learning effects. International Journal of Production Economics, 115(1), $143-50$.

[15] Khouja, M., (2000). The economic lot and delivery scheduling problem: common cycle, rework, and variable production rate. IIE Transactions 32, 715-725.

[16] Koh., S.G., Hwang, H., Sohn, K.I., Ko, C.S., (2002). An optimal ordering and recovery policy for reusable items. Computers \& Industrial Engineering 43, 59-73.

[17] Kumar. M., Chauhan. A., Kumar. P., (2011). Economic Production Lot size Model with Stochastic Demand and Shortage Partial Backlogging Rate under Imperfect Quality Items. Int. J. of Advanced Science \& Tech. 31, 1-22.

[18] Mishra. V. N., (2007). Some Problems on Approximations of Functions in Banach Spaces, Ph.D. Thesis. Indian Institute of Technology, Roorkee - 247 667, Uttarakhand, India.

[19] Mishra. V. K, Singh. L.S., Kumar. R., (2013). An inventory model for deteriorating items with timedependent demand and time-varying holding cost under partial backlogging. Journal of Industrial Engineering International, doi:10.1186/2251-712x-9-4.

[20] Mukhopadhyay. A., Goswami. A., (2015). Economic production quantity model for three type imperfect items with rework and learning in setup. An international journal of Optimization and control: Theories \& Applications, 4(1), 57-65.

[21] Pal.S., Mahapatra. G.S., Samanta. G.P. (2015). Aproduction model for deteriorating item with ramp type demand allowing inflation and shortages under fuzziness. Economic modelling 46, 334- 345.

[22] Rezaei. J., Davoodi, M., (2008). A deterministic, multi-item inventory model with supplier selection and imperfect quality. Applied Mathematical Modelling, 32(10), 2106-16.

[23] Rezaei. J., Salimi. N., (2012). Economic order quantity and purchasing price for items with imperfect quality when inspection shifts from buyer to supplier. Int. J. Production Economics 137, $11-18$.

[24] Sarkara. B., Cárdenas-Barrón. L.E., Sarkar. M., Singgih. M.L., (2014). An economic production quantity model with random defective rate, rework process and backorders for a single stage production system. Journal of Manufacturing Systems, 33, 423-435.

[25] Schrady, D.A., (1967). A deterministic inventory model for repairable items. Naval Research Logistics 48, 484-495.

[26] ShilpiPal, Mahapatra. G.S., Samanta. G.P. (2015). Aproduction model for deteriorating item with ramp type demand allowing inflation and shortages under fuzziness. Economic modelling 46, 334345.

[27] Singh, S. R., Shalini. J., Pareek. S., (2014). An economic production model for time dependent demand with rework and multiple production setups. International Journal of Industrial Engineering Computations 5, 305-314.

[28] Singh, S.R., Agarwal. A., Smita Rani., (2015). Mathematical production inventory model for deteriorating items with time dependent demand rate under the effect of inflation and shortages. International Journal of Computer \& Mathematical Sciences, 4, 138-148.

[29] Tai, A. H., (2013). Economic production quantity models for deteriorating/imperfect products and service with rework. Computers \& Industrial Engineering, 66(4), 879-88.

[30] Vandana, B.K. Sharma., (2015). An EPQ inventory model for non-instantaneous deteriorating item under trade credit policy. International Journal of Mathematical Sciences and Engineering Applications. (IJMSEA), 9 (No. I), pp. 179-188.

[31] Vandana, B.K. Sharma., (2015). An inventory model for Non-Instantaneous deteriorating items with quadratic demand rate and shortages under trade credit policy. Journal of Applied Analysis and Computation, in press.

[32] Vandana, B.K. Sharma., (2016). An EOQ model for retailers partial permissible delay in payment linked to order quantity with shortages. Mathematics and Computers Simulation.

http://dx.doi.org/10.1016/j.matcom.2015.11.008 
[33] Wee, H.M., Yu, J., Chen, M.C., ( 2007). Optimal inventory model for items with imperfect quality and shortage backordering. Omega, 35(1), 7-11.

[34] Widyadana, G. A., Wee, H. M. (2012). An economic production quantity model for deteriorating items with multiple production setups and rework. International Journal of Production Economics, 138(1), 62-67.

[35] Yassine, A., Maddah, B., Salameh, M., (2012). Disaggregation and consolidation of imperfect quality shipments in an extended EPQ model. International Journal of Production Economics, 135(1), 345-52.

[36] Yoo, S.H., Kim, D.S., Park, M.S., (2009). Economic production quantity model with imperfectquality items, two-way imperfect inspection and sales return. International Journal of Production Economics 121, 255-265.

\section{NOTES ON CONTRIBUTORS}

Mr T.Sekar is a Part-Time research scholar, Department of Mathematics, Gandhigram Rural Institute -Deemed University, Gandhigram - 624302, Tamil Nadu, India. He received his B. Sc degree from Govt. arts college karur, Bharathidasan University, M. Sc and M. Phil degree from National College, Trichy, Bharathidasan University, Tamil Nadu, India. Currently, he is working in EBET Group of Institutions, Tirupur, Tamil Nadu, India. His research interests are in the field of inventory management

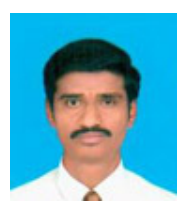
and control, optimization techniques and their applications.

Dr R. Uthayakumar was born in Dindigul, India, in 1967. He received the PhD degree from the Gandhigram Rural Institute -Deemed University, Gandhigram, Tamil Nadu, India, in 2000. Currently, he is a Professor \& Head, Department of Mathematics, Gandhigram Rural Institute -Deemed University, Gandhigram. He has done research in the area of functional analysis. His current research interests are primarily in the field of optimization and the Theory of Fractal Analysis. He is also interested in finding out the

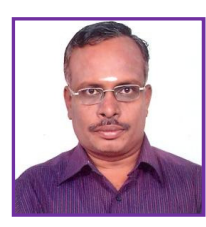
general mathematical model in the field of inventory management and supply chain. To his credit, he has published many research articles in the area of inventory management and supply chain in reputed international journals. Moreover, he is guiding many scholars in the above said areas. 